\title{
Relationship of Internal Heat Necrosis of Potato to Time and Temperature after Planting
}

\author{
S.B. Sterrett ${ }^{1}$ \\ Eastern Shore Agricultural Experiment Station, Virginia Polytechnic Institute and State University, \\ Painter, VA 23420
}

M.R. Henninger ${ }^{2}$

Department of Horticulture, Cook College, Rutgers University, New Brunswick, NJ 08903

G.S. Lee $^{3}$

Arkansas Cooperative Extension Service, University of Arkansas, Little Rock, AR 72203

Additional index words. Solanum tuberosum, internal brown spot, internal rust spot, physiological necrosis, accumulated heat units

\begin{abstract}
The progression of internal heat necrosis (IHN) of 'Atlantic' potato was studied in seven plantings in two locations (Virginia and New Jersey) over 3 years. The incidence (percentage of tubers with necrosis), severity (rating), and distribution (percentage of $1 / 8$ pieces with necrosis per tuber) of IHN increased with successive harvests, but varied with year and location. Significant but weak linear correlation coefficients were found for the IHN variables of incidence, rating, and distribution with either time in days after planting (DAP), yield, or percentage of tubers $>64 \mathrm{~mm}$ in diameter. Models were developed using stepwise regression to relate IHN variables with DAP, yield, percentage of large tubers, and various temperature and rainfall measurements. Time (DAP), penalty (DAP to first occurrence of three consecutive days of negative accumulated heat units), and rainfall (1 to 60 DAP) were significant variables in regression models for incidence and rating. While DAP and penalty were significant variables in the regression model for distribution, the variable rainfall was not included in the model. These findings indicate that the potential of IHN in 'Atlantic' varies with the growing season, and is influenced by more than one environmental
\end{abstract}

The potato cultivar Atlantic combines 'the potential for high yield and high specific gravity with desirable tuber characteristics for chip processing (Webb et al., 1979). While preferred by many potato chip processors, 'Atlantic' is susceptible to a disorder commercially referred to as IHN. For the grower, this disorder greatly increases the risk of economic loss from unsalable tubers.

Symptoms of IHN in 'Atlantic' include round-to-irregular light tart to reddish-brown spots or blotches occurring primarily in the parenchyma tissue internal to the vascular ring. Necrotic tissue appears at or near harvest, and generally in the largest tubers first. While the necrosis occurs initially toward the apical end of the tuber, the color intensity and tuber area affected increase over time.

The symptoms found in 'Atlantic' are similar to some of those reported for IBS (Atanasoff, 1926; Friedman, 1955; Hiller et al., 1985; Iritani et al., 1984) and also to some symptoms of IHN (O'Brien and Rich, 1976; Zimmerman-Gries, 1964). As in IBS, the necrosis in 'Atlantic' occurs in tubers throughout the hill profile (Hiller et al., 1985; Iritani et al., 1984; Larson and Albert, 1945). IHN has been associated with tubers within the top $5 \mathrm{~cm}$ of the soil surface (Hooker, 1981; Larson and Albert, 1945). However, necrosis in 'Atlantic', like that reported for IHN, appears at or near harvest (O'Brien and Rich, 1976; Zimmerman-Gries, 1964). Internal brown spot reportedly

\footnotetext{
Received for publication 16 Mar. 1990. Research supported in part by a gran from Anheuser Busch Co. We gratefully acknowledge the assistance of C.P. Savage, Jr. and F.W. Punk with the field studies and M. Lentner with the regression analyses. The cost of publishing this paper was defrayed in part by the payment of page charges. Under postal regulations, this paper therefore must be hereby marked advertisement solely to indicate this fact.

'Associate Professor.

${ }^{2}$ Professor.

${ }^{3}$ Extension Horticulturist-Vegetables.
}

occurs at various time throughout the growing season (Hiller et al., 1985; Hooker, 1981; Larson and Albert, 1945).

Although IBS is generally considered to exhibit no external symptoms (Iritani, 1984; Larson and Albert, 1945; O’Brien and Rich, 1976), Atanasoff (1926) associated irregular-shaped tubers with IBS. Tubers with IHN have been reported to exhibit blackened apical eyes and shrunken surface lesions (Hooker, 1981; Zimmerman-Gries, 1964). 'Atlantic' tubers with IHN exhibit no external symptoms.

While differences have been noted in the development of IBS in 'Russet Burbank' in the northwestern United States and IHN in 'Atlantic', the symptoms seem to be quite similar (L.K. Hiller, personal communication). Necrotic tissue in potato tubers has also been described as internal rust spot (Davies and Talbot, 1989), internal browning (Ellison and Jacob, 1952; Wolcott and Ellis, 1959), physiological internal necrosis (Larson and Albert, 1945, 1949), internal brown fleck (Novak et al., 1986), and chocolate spot (Kamal and Marroush, 1971).

Differences in cultivar susceptibility have been reported in several growing areas, with yearly variation in incidence and severity (Ellison, 1953; Ellison and Jacob, 1952; Larson and Albert, 1949; Wolcott and Ellis, 1959). Increased incidence of necrosis has been associated with growing seasons having above normal temperatures (Ellison and Jacob, 1952; Larson and Albert, 1945; Wolcott and Ellis, 1959), and below normal precipitation (Ellison and Jacob, 1952; Larson and Albert, 1945). However, the influence of environmental factors on the incidence and severity of IHN has not been quantified.

In most of the studies reported to date, IBS and IHN have been evaluated as percentage of affected tubers at a single harvest with no attempt to describe the progression of the disorder

Abbreviations: DAP, days after planting; IBS, internal brown spot; IHN, internal heat necrosis. 
or the intensity of the discoloration. The objectives of this study were to a) gain a better understanding of the progression of the disorder through successive harvests; b) to examine the influence of year and location of the expression of the disorder; and c) to examine the influence of environmental factors on both severity and the percentage of tubers affected with IHN.

\section{Materials and Methods}

'Atlantic' potatoes were planted in 1986, 1987, and 1988 on a Bojac sandy loam (coarse-loamy, mixed, thermic Typic Hapludult) at the Eastern Shore Agricultural Experiment Station, Painter, Va., on an Oura loam (fine-loamy, mixed, masic, Typic Hapludult) in 1986 and 1987, and on a Sassafras sandy loam (fine-loamy, siliceous, masic, Typic Hapludult) in 1988 at the Rutgers Research and Development Center, Bridgeton, N.J. The planting dates varied with growing seasons and locations (Table 1). However, uniform fertility levels included $\left(\mathrm{kg} \cdot \mathrm{ha}^{-1}\right) 112 \mathrm{~N}$ $44 \mathrm{P}-83 \mathrm{~K}$ banded at planting were maintained. All studies were sidedressed with $56 \mathrm{~kg} \mathrm{~N} / \mathrm{ha} 6$ to 7 weeks after planting. Recommended cultural practices were followed regarding pesticide applications. Irrigation was applied as needed. A randomized complete block design was used for all plantings, with six replications in New Jersey [four in 1986 late planting (NJ86L)] and four in Virginia.

Within-row spacing of seed pieces was $0.3 \mathrm{~m}$ in Virginia and $0.23 \mathrm{~m}$ in New Jersey, reflecting commercial spacing in the two growing areas. In Virginia, 3. 0-m plots were dug by hand (Table 1). The length of the mechanically harvested plots in New Jersey varied between years from 7.3 to $10 \mathrm{~m}$.

In all trials, tubers were mechanically sized and weighed. The progression of IHN was measured by successive harvests in each growing season at each location. Incidence of IHN was determined by cutting tubers with diameters of 64 to $83 \mathrm{~mm}$ and $>83 \mathrm{~mm}$ and recording the number of tubers with necrosis. The distribution of IHN was determined by cutting tubers into quarters longitudinally and then cutting these in cross section to expose surfaces on eight pieces (Ellison, 1953). Both the incidence of necrosis and the percentage of pieces with necrosis (distribution) were determined for each harvest except for distribution in Virginia in 1986. All tubers were cut in Virginia; because of the larger plot size, a maximum of 20 tubers per size category was cut in New Jersey. Severity (rating) was determined subjectively using scale where $9=$ no visible necrosis and $1=$ extreme necrosis (Fig. 1). This scale is consistent with the rating for internal and external defects in the NE-107 interregional potato project (Porter et al., 1990). Although tubers with internal defects are considered to be out of USDA No. 1 grade (offgrade), when internal defects exceed $5 \%$ by weight of the fresh product, potato chip processors use the finished product to determine offgrade. Since the early stages of IHN (rating > 7.0) are often masked during frying for potato chips (J.W. Molnar, personal communication), samples were considered commercially offgrade when the mean IHN rating was $\leq 7.0$ for tubers $>64 \mathrm{~mm}$ in diameter.

Statistical analyses of incidence and distribution were completed using the arcsin-square root variance stabilizing transformation (Snedecor and Cochran, 1967). Because the incidence and severity of IHN increased with each harvest, the comparison of the progression between growing seasons and locations was completed using a regression equation for each planting rather than an individual data point. The dependent variables were incidence, rating, and distribution. Independent variables included DAP and growing season. The hypothesis that the progression of IHN was the same over growing season and location was investigated by testing the simultaneous equality of the slope and intercepts of the regression equations for incidence, rating, and distribution for each planting using the following equation:

$$
\mathrm{F}=\frac{\left(\mathrm{SS}(\text { season })+\mathrm{SS}\left(\text { time }^{*} \text { season }\right)+\mathrm{SS}\left(\text { time }^{2 *} \text { season }\right)\right) /(\mathrm{n}-1)}{\text { Mean square error }}
$$

where $\mathrm{n}-1=(($ location $*$ season $)-1)$ and time $=$ DAP $(M$. Lentner, personal communication).

Daily maximum and minimum air temperature and amount of precipitation or irrigation were recorded. The descriptive variables associated with temperature and rainfall are summarized in Table 1. Models were examined using stepwise regression analyses (SAS, 1985) to explain the variability in the progression of IHN (incidence, rating, and distribution) over location and growing season. Independent variables included DAP and those associated with temperature and rainfall. Temperature variables were developed using the heat-sum model of Lee and Sterrett (1989) that included a reduction in calculated heat units when the maximum air temperature was $>25 \mathrm{C}$ or the minimum $>21 \mathrm{C}$, thereby reflecting excessive maxima and minima. The slope of the regression equation described the increase in ac-

Table 1. Planting and harvest dates, average maximum and minimum temperatures, and temperature variables used in stepwise regression analyses.

\begin{tabular}{|c|c|c|c|c|c|c|c|c|c|c|c|}
\hline \multirow[b]{2}{*}{ Year } & \multirow{2}{*}{$\begin{array}{c}\text { Planting } \\
\text { date }\end{array}$} & \multirow{2}{*}{$\begin{array}{c}\text { No. } \\
\text { of harvest }\end{array}$} & \multicolumn{2}{|c|}{$\begin{array}{c}\text { Harvest } \\
\text { (DAP) }\end{array}$} & \multicolumn{7}{|c|}{ Environmental variables } \\
\hline & & & First & Last & $T \min 60^{2}$ & $\operatorname{Tmax} 60$ & Nave & Slope60 & Penalty & Rain60 & Nrain60 \\
\hline \multicolumn{12}{|c|}{ Virginia } \\
\hline 1986 & 24 Mar. & 4 & 86 & 119 & 0 & 17 & 6 & 3.85 & 67 & 40 & 11 \\
\hline 1987 & 9 Apr. & 4 & 81 & 103 & 4 & 22 & 1 & 3.99 & 51 & 64 & 15 \\
\hline 1988 & 30 Mar. & 10 & 80 & 122 & 0 & 8 & 8 & 3.89 & 59 & 162 & 23 \\
\hline \multicolumn{12}{|c|}{ New Jersey } \\
\hline $1986 \mathrm{E}^{\mathrm{y}}$ & 2 Apr. & 10 & 98 & 140 & 5 & 14 & 12 & 2.25 & 58 & 133 & 10 \\
\hline $1986 \mathrm{~L}$ & 23 Apr. & 9 & 75 & 115 & 8 & 31 & 2 & 3.42 & 37 & 73 & 9 \\
\hline 1987 & 12 Apr. & 7 & 93 & 135 & 2 & 20 & 7 & 3.12 & 46 & 102 & 11 \\
\hline 1988 & $24 \mathrm{Mar}$. & 7 & 105 & 147 & 0 & 4 & 16 & 3.33 & 66 & 188 & 17 \\
\hline
\end{tabular}

${ }^{\mathrm{z}}$ Tmin60 = Days with minimum temperature $\geq 21 \mathrm{C}, 1$ to 60 DAP; Tmax60 = Days with maximum temperature $\geq 25 \mathrm{C}, 1$ to 60 DAP; Nave $=$ Total no. of days that $(\operatorname{Tmax}+$ Tmin $) / 2 \leq 10 \mathrm{C} ;$ Slope $60=$ Slope of regression line of accumulated heat units1 to 60 DAP (Lee et al., 1989); Penalty = DAP to first three consecutive days of negative heat units; Rain60 = Rainfall $(\mathrm{mm})$ 1 to 60 DAP; Nrain $60=$ Rain events in first 60 DAP.

${ }^{y}$ Two planting dates in New Jersey in 1986, designated as early (E) and late (L). 


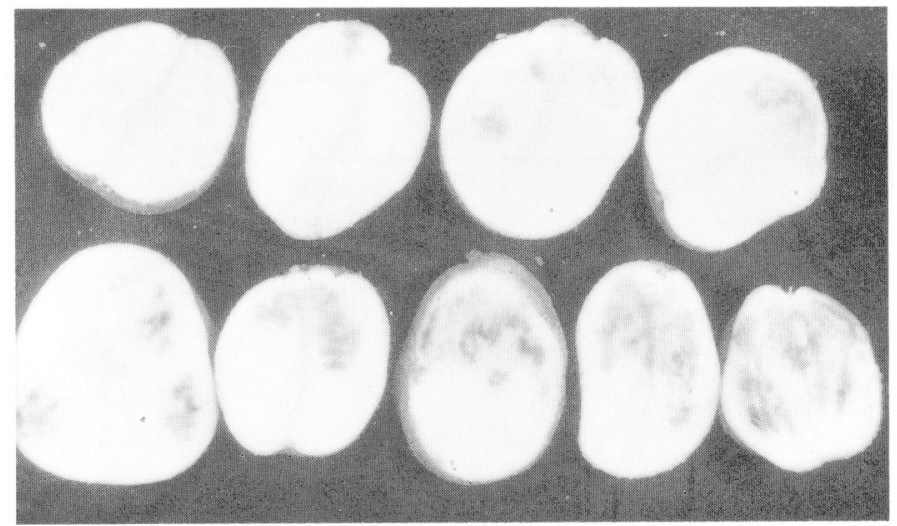

Fig. 1. Subjective scale used to determine severity of IHN. Tubers cut longitudinally. Upper left, rating $=9$; lower right $=1$. The necrotic tissue has diffuse boundaries and, therefore, appears to be out of focus.

Table 2. Use of F statistic to compare the progression of incidence, severity (rating of IHN), and distribution of necrosis between years and locations.

\begin{tabular}{lc}
\hline \hline Variable & F statistic \\
\hline Incidence & $25.04^{* *}$ \\
Over location and years & $13.36^{* *}$ \\
Over years - Virginia & $19.89^{* *}$ \\
Over years-New Jersey & \\
Rating & $34.82^{* *}$ \\
Over location and years & $17.78^{* *}$ \\
Over years-Virginia & $36.56^{* *}$ \\
Over years-New Jersey & \\
Distribution & $22.86^{* *}$ \\
Over location and years & $9.57^{* *}$ \\
Over years-Virginia & $34.37^{* *}$ \\
Over years-New Jersey & \\
\hline
\end{tabular}

**Significant at $\alpha=0.01$.

cumulated heat units 60 or 90 DAP (slope60, slope90). Penalty was defined as the first occurrence of three consecutive days of negative heat units.

Rainfall variables included total rainfall, from planting up to and including 60 DAP (rain60) and 90 DAP (rain90). Time (DAP), yield, and the percentage of large tubers were also included. Multi-colinearity from closely related temperature or rainfall variables was avoided by limiting the variables in any given model.

\section{Results and Discussion}

The progression of IHN as measured by incidence, rating, and distribution over successive harvests varied significantly with location and growing season (Table 2). The first visible symptoms of IHN (first trace) occurred earlier in Virginia than in either the early planting in 1986 (NJ86E) or in 1988 (NJ88) in New Jersey (Fig. 2).

The first trace of IHN in NJ86L occurred 21 DAP earlier and nine calendar days earlier than in NJ86E. However, the time elapsed from first trace to offgrade was 5 days longer for NJ86L. Both Ellison and Jacob (1952) and Iritani et al. (1984) reported reduced IBS with later plantings, although the former noted more IBS in tubers harvested 4 weeks after maturity than in those harvested soon after the vine died. The difference between the progression of IHN in 'Atlantic' in these studies and in studies using 'Katahdin' or 'Russet Burbank' maybe due in part
VIRGINIA

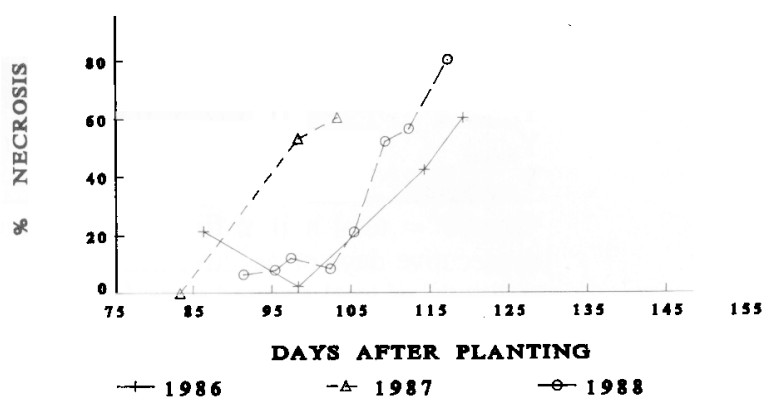

NEW JERSEY

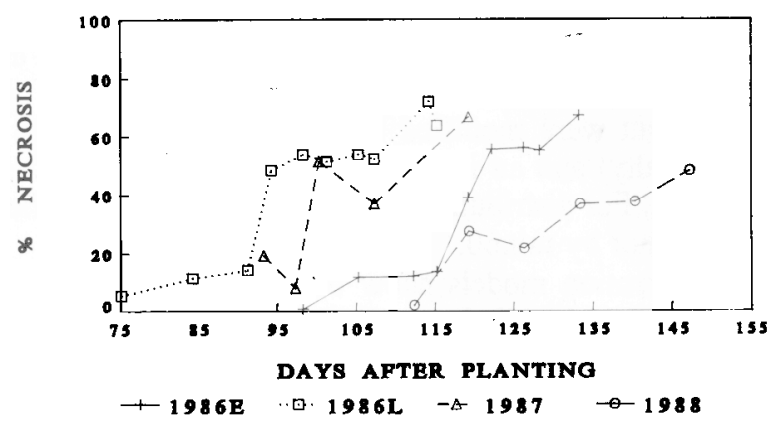

Fig. 2. Comparison of the progression of IHN over two locations and 3 years. Length of each line represents interval from first visible symptom of IHN to offgrade.

Table 3. Correlation coefficients between internal, heat necrosis, DAP and yield parameters. $\mathrm{N}=244$.

\begin{tabular}{lccccc}
\hline \hline Variable $^{z}$ & Rating $^{\mathrm{y}}$ & Incidencey & Distribution & DAP & Yield \\
\hline Incidence & $-0.73^{* *}$ & & & & \\
Distribution & $-0.71^{* *}$ & $0.89^{* *}$ & & & \\
DAP & $-0.57^{* *}$ & $0.47^{* *}$ & $0.44^{* *}$ & & \\
Yield & $-0.44^{* *}$ & $0.47^{* *}$ & $0.43^{* *}$ & $0.57^{* *}$ & \\
\% largex & $-0.34^{* *}$ & $0.37^{* *}$ & $0.29^{* *}$ & $0.05^{\mathrm{NS}}$ & $0.50^{* *}$ \\
\hline
\end{tabular}

${ }^{2}$ Incidence $=$ percentage of tubers with IHN; distribution = percentage of pieces with visible symptoms of IHN when each tuber examined was cut into eight pieces.

'Subjective scale, $9=$ no visible symptoms, $1=$ severe.

xPercentage of tubers (by wt) with diameter $>64 \mathrm{~mm}$.

NS, **Nonsignificant or significant at $P=0.01$, respectively.

to cultivar differences or to the stage of progression at the time of harvest. For most studies reported to date, the evaluation of necrosis has been based on a single harvest with no rating of the severity of the disorder (Atanasoff, 1926; Iritani et al., 1984; Larson and Albert, 1945; Wolcott and Ellis, 1959; ZimmermanGries, 1964).

Linear correlation coefficients were used to determine the relationship between incidence and severity of IHN and DAP, tuber yield, and the percentage of tubers $>64 \mathrm{~mm}$ in diameter. Incidence of necrosis, rating, and distribution were significantly but weakly correlated with DAP, yield, and percentage of large tubers (Table 3 ). The negative coefficients for rating reflect the reversed rating scale in which $9=$ no visible symptoms.

The weak relationship between the development of IHN and yield components, even though the symptom appeared first in the lar $r$ tubers, suggests a more direct environmental effect on the development and severity of IHN. Both Friedman (1955) 
Table 4. Regression models describing the influence of temperature and rainfall variables on IHN using stepwise regression.

\begin{tabular}{llcc}
\hline \hline $\begin{array}{l}\text { Dependent } \\
\text { variables }\end{array}$ & \multicolumn{1}{c}{ Independent variables } & $R$ & $\mathrm{C}(\mathrm{P})^{\mathrm{y}}$ \\
\hline $\mathrm{Y}_{\text {lncidence }}$ & $=-0.157+0.011 \mathrm{X}_{\mathrm{DAP}}-0.009 \mathrm{X}_{\text {Penalty }}-0.002 \mathrm{X}_{\text {Rain60 }}$ & $0.439^{* *}$ & 3.03 \\
$\mathrm{Y}_{\text {Rating }}$ & $=11.3-0.057 \mathrm{X}_{\mathrm{DAP}}+0.035 \mathrm{Y}_{\text {Penalty }}+0.009 \mathrm{X}_{\text {Rain60 }}$ & $0.637^{* *}$ & 3.62 \\
$\mathrm{Y}_{\text {Distribution }}$ & $=0.205+0.011 \mathrm{X}_{\mathrm{DAP}}-0.019 \mathrm{X}_{\text {Penaly }}$ & $0.541^{* *}$ & 3.94 \\
\hline
\end{tabular}

${ }^{2}$ Rain60 = total rain in first $60 \mathrm{DAP}$; and Penalty $=$ days from planting to penalty [first three consecutive days of negative heat unit accumulation (Lee and Sterrett, 1989)].

${ }^{y}$ Measure of total squared error (SAS, 1985).

**Significant at $\alpha=0.01$.

and Wolcott and Ellis (1959) associated yearly differences in the incidence and severity of IBS with recurring periods of high temperature followed by below average rainfall.

The stepwise regression equations describing the influence of environmental factors differ for incidence, rating, and distribution (Table 4). Incidence of necrosis and rating were higher with DAP, but were modified by a delay in the days to first penalty (penalty) and an increase in rainfall during the first 60 days (rain60). For distribution, however, DAP was modified by penalty, but not by rain60.

These regression models show the complex relationship of time and environmental factors on the development of IHN. Differences in observed necrosis over a period of years have been reported in several other studies, suggesting that one or more seasonal or environmental triggers may be associated with the development of IHN (Ellison and Jacob, 1952; Friedman, 1955; Larson and Albert, 1949; Wolcott and Ellis, 1959). Nelson et al. (1979) also found a complex plant and environmental interaction associated with the development of hollow heart, another disorder of potatoes.

The stepwise regression models indicate that both maximum and minimum temperatures, as reflected in the penalty, had some influence on the progression of IHN. The environmental influence can also be seen in the progression of the incidence of necrosis (Fig. 2). In 1988 in New Jersey, IHN started later in the growing season and the incidence was lower than that of the late planting in 1986 (1986L) or 1987. In the cool, wet spring of 1988 , the first penalty occurred $>20$ days later than in either 1986L or 1987, while the rainfall in 1988 was substantially higher (Table 1). Benoit et al. (1986) found that plant growth was a function of the combined influence of maximum and minimum temperatures and that each daytime maximum had an optimum night temperature. The variables appearing in the regression models for incidence, rating, and distribution suggest that the development of IHN is not necessarily a simple response to high temperatures as previously suggested (Ellison and Jacob, 1952; Hooker, 1981; Larson and Albert, 1945), but rather a combination of responses to several environmental stimuli. Although a variable representing rainfall and irrigation was included, it was not selected in the stepwise regression analysis using maximum $R^{2}$ improvement. Additional studies in a controlled environment would be needed to clarify the relationship of maximum and minimum temperatures and soil moisture to the onset and progression of IHN.

Information gained from these studies on the influence of temperature and rainfall on the incidence, severity, and distribution of IHN was useful in the development of predictive models for onset of IHN and production of off-grade tubers (Sterrett et al., 1991). The assessment of the potential for IHN early in the growing season will provide growers with a management tool for scheduling harvest to optimize yield of 'Atlantic' while minimizing the risk of economic loss from IHN.

\section{Literature Cited}

Atanasoff, D. 1926. Sprain or internal brown spot of potatoes. Phytopathology 16:711722.

Benoit, G.R., W.J. Grant, and O.J. Devine. 1986. Potato top growth as influenced by day-night temperature differences. Agron. J. 78:264-269.

Davies, H.U. and L.S. Talbot. 1989. Studies on the physiological basis for genotypic variation in susceptibility of tubers to internal rust spot (IRS) - A calcium related disorder. Amer. Potato J. 66:514. (Abstr.)

Ellison, J.H. 1953. Varietal susceptibility to internal brown spot of potatoes. Amer. Potato J. 30:92-94.

Ellison, J.H. and W.C. Jacob. 1952. Internal browning of potatoes as affected by date of planting and storage. Amer. Potato J. 29:241-252.

Friedman. B.A. 1955. Association of internal brown spot of potato tubers with hot, dry weather. Plant Dis. Rptr. 39(1):3744.

Hiller, L.K., D.C. Keller, and R.E. Thornton. 1985. Physiological disorders of potato tubers. In: P.H. Li (ed.). Potato physiology. Academic, Orlando, Fla.

Hooker, W.J. 1981. Compendium of potato diseases. Amer. Phytopathol. Soc., St. Paul, Minn.

Iritani, W.M., L.D. Weller, and N.R. Knowles. 1984. Factors influencing incidence of internal brown spot in Russet Burbank potatoes. Amer. Potato J. 61:335-343.

Kamal, A.L. and M. Marroush. 1971. Control of chocolate spot in potato tubers by foliar spray with 2-chlorethylphosphonic acid. HortScience 6:42.

Larson, R.H. and A.R. Albert. 1945. Physiological internal necrosis of potato tubers in Wisconsin. J. Agr. Res. 71:487-505.

Larson, R.H. and A.R. Albert. 1949. Relation of potato varieties to incidence of physiological internal tuber necrosis. Amer. Potato J. 26:427-431.

Lee, G.S. and S.B. Sterrett. 1989. Heat-sum model to determine yield and onset of internal heat necrosis for 'Atlantic' potatoes. Amer. Potato J. (In press.)

Nelson, D.C., D.A. Jones, and M.C. Thoreson. 1979. Relationship between weather, plant spacing, and the incidence of hollow heart in Norgold Russet Potatoes. Amer. Potato J. 56:581-586.

Novak, V.J., G.D. Mann, and G.N. Schrodter. 1986. Effects of age at harvest and irrigation near maturity on the incidence of internal brown fleck in potato tubers. Austral. J. Expt. Agr. 26:129-132.

O'Brien, M.J. and A.E. Rich. 1976. Potato diseases. U.S. Dept. Agr., Agr. Hdbk. 474.

Porter, G.A., J.A. Sisson, E.S. Plissey, L.S. Morrow, T.R. Tam, H. DeJong, M.R. Henninger, J.B. Sieczka, D.D. Moyer, D.E. Halseth, M.A. Bennett, R.H. Cole, S.B. Sterrett, and R.J. Young. 1990. Performance evaluations of potato clones and varieties in the northeastern states-1989. Maine Agr. Expt. Sta. 708.

SAS Institute, Inc. 1985. SAS user's guide: Statistics. SAS Institute, Inc., Cary, N.C.

Snedecor, G.W. and W.G. Cochran. 1967. Statistical methods. 6th ed. The Iowa State Univ. Press, Ames.

Sterrett, S.B., G.S. Lee, M.R. Henninger, and M. Lentner. 1991. Predictive model for onset and development of internal heat necrosis of 'Atlantic' potato. J. Amer. Soc. Hort. Sci. 116:701-705.

Webb, R.E., D.R. Wilson, J.R. Shumaker, B. Graves, M.R. Henninger, J. Watts, J.A. Frank, and H.J. Murphy. 1979. Atlantic: A new potato variety with high solids, good processing quality, and resistance to pests. Amer. Potato J. 55:141145 .

Wolcott, A.R. and N.K. Ellis. 1959. Internal browning of potato tubers: varietal susceptibility as related to weather and cultural practices. Amer. Potato J. 36:394403.

Zimmerman-Gries, S. 1964. The occurrence of potato heat-necrosis symptoms in. Israel and the use of affected tubers as seed. European Potato J. 7:112-118. 